Article

\title{
The Impact of Institutional Quality and Efficient Cohesion Investments on Economic Growth Evidence from Italian Regions
}

\author{
Roberta Arbolino * and Raffaele Boffardi \\ University of Naples “L'Orientale”, 80134 Naples, Italy; raffaele.boffardi@hotmail.it \\ * Correspondence: rarbolino@unior.it
}

Received: 13 June 2017; Accepted: 8 August 2017; Published: 14 August 2017

\begin{abstract}
Literature stresses that efficient institutions are necessary to achieve the highest returns from public policies. It has been recognized by the European Union (EU) that regional institutions have a fundamental role in obtaining the highest results from Cohesion and Structural investments, which represent the main fiscal and anticyclical instruments available for the regions. The paper aims at analyzing the impact of the quality of regional governments, and their management of EU cohesion funds on the economic growth of Italian regions. In order to measure the quality of institutions, we have combined the Institutional Quality Index (IQI) with a set of efficiency indexes, calculated in order to evaluate the ability of regional policymakers to manage European Funds. We conduct a two-way fixed effect panel regression model during the period between 2007 and 2015. The results underline that, in general, Cohesion investments and IQI are positively related to the regional growth; instead, efficiency indexes are important key factors mainly in the Southern area, characterized by structural weaknesses.
\end{abstract}

Keywords: cohesion funds; economic growth; government quality; efficiency index

\section{Introduction}

The ten-year economic crisis has seriously damaged Italian economic performances. Despite the recent modest growth of GDP and employment, differently from many other European countries, Italian economic indicators are still far from pre-crisis levels. At the end of 2016, the Italian GDP was 7\% lower than 2008, while France, Germany, and Spain had already recovered to their pre-crisis levels [1,2]. Furthermore, the economic crisis has contributed to increasing divergences among the Italian regions. In the South, the decrease in employment has been just partially recovered, while per capita GDP levels are $44 \%$ lower than in the North area [3].

In this context, European Union (EU) Cohesion policy has continuously supported regional economies in order to strengthen long-term economic and social convergence (art. 174, Treaty on the Functioning of the European Union, TFUE). Such investments have been arranged by means of three EU-managed funds: the Cohesion Fund, created after the Maastricht Treaty in 1992; the European Regional Development Fund (ERDF); and, and the European Social Fund (ESF), together referred to as the "European Structural Funds". The main difference among these funds is the level on which they operate: Cohesion Fund mainly operates on the national level, in contrast to the regional one, characterizing the Structural Funds [4]. Due to the economic crisis, Cohesion policy has been reformed to achieve short-term objectives and help countries to react faster to the recession [5]. Despite the support of EU funds, according to the main economic data [3], Italian regional gaps have increased, also because of the different impacts of public investments among the regions [6].

Understanding the role of regional policymakers on investments financed by Structural funds is a main issue for economic scholars, in order to explain regional imbalances [7-9]. Nowadays, there is a 
widespread belief that the different administrative and political capabilities of regional governments become relevant in the implementation of development policies [10-12]. In fact, according to the Sixth Cohesion Report [13], "poor institutions can, in particular, hinder the effectiveness of regional development strategies".

The objective of this research is to measure the returns of regional investments realized through structural funds, considering both the spending ability of regional policymakers and the institutional quality of each region. In order to assess these aspects, we have combined the Institutional Quality Index [14] with a set of efficiency indicators elaborated by us, explaining the efficiency in terms of spending capability.

Our contribution is linked to the literature investigating the institutional factors that explain the presence of regional differences in the impact of EU cohesion policy across Italian regions [7]. We expand the current studies by including a different dimension in the analysis compared to the current economic literature: the qualitative aspect, which is the only one usually taken into account in the economic analysis $[10,15]$, has been accompanied by an innovative managerial one. This second aspect has been conceived as the ability of financing projects and bringing them to a conclusion within the timelines of the 2007-2013 Cohesion Program, and it has been assessed through the three indexes that we have elaborated. The paper is organized as follows. Section 2 provides an explanation about the European Cohesion and Structural Funds, while 2.1 presents the main empirical evidences. Section 3 shows a review of the literature related to both the effects of fiscal policy and the impact of the quality of government on regional economic growth, and a description of the set of indexes that we used in the following descriptive and econometrical analysis. Sections 4 and 5 discuss the econometrical models and the results of the analysis. The final discussion and the following conclusions are contained in Section 6.

\section{The Quality of Public Administrations in the Use of Structural Funds}

The effects of public spending on national economic growth have been deeply investigated, but according to Mitze and Matz (2015) [16] it has become fundamental to understand the impact of fiscal policy on sub-national economic growth. Currently, several hypotheses have been proposed about the impact of fiscal policies. According to Lago-Penas and Ventelou (2006) [17], the size of sub-national administrative divisions affects fiscal policy, and the effects of this policy depend on the proximity of the authority to the territory.

Srithongrung and Sanchéz-Juaréz (2015) [18], with reference to Mexico, claim that public finance at a regional level can be used to stabilize regional growth, by having a major effect than foreign direct investment. The same result is suggested by Coetzee and Kleynhans (2017) [19] after having studied the usage of public capital across the provinces of South Africa.

Otherwise, by studying the Italian case, Auteri and Costantini (2004) [20] found that the amount of resources transferred by Italian government to local authorities, mainly regions, has not always had positive effects on growth. In Southern and Central Italy, in particular, these resources are often used as a redistributive tool rather than being invested in infrastructures, which would maximize economic growth in the long term.

Among the fiscal policy instruments available to European regions, the investments by Structural and Cohesion funds are nowadays the main ones [21]. They are the major EU budget heading, featuring an increasing trend: in the 2007-2013 programming period, 278 billion euro had been allocated [22]; while, in the 2014-2020 planning, the share reached 367 billion euro, moving from $28 \%$ to $34 \%$ of the total EU budget [23].

Since its introduction in 1975, the EU Cohesion policy has mainly aimed at promoting economic convergence, social cohesion, imbalance reduction, and sustainable and long-term growth among European regions [24]. The 2007-2013 Cohesion policy programme had three specific objectives: "Convergence", "Regional Competitiveness and Employment", and "Territorial Cooperation". 
The EU has destined the largest part of its structural funds to the objective "Convergence" (75\% of the total), whose investments are financed by all three of the funds in order to strengthen the growth in poorer areas. "Objective Convergence" promotes investments in the regions that have an annual per capita GDP lower than the $75 \%$ European average value. The allocation is defined in accordance with the "principle of territorial concentration", which is described in the Third Cohesion Report [25] as one of the main pillars of EU cohesion policy.

As a consequence of both the Great Recession and of the weak results achieved [26,27], although structural fund investments were thought of as long-term structural actions, they have become part of the European Economic Recovery Plan [28,29], a package of short-term counter-cyclical policies based on targeted measures [30]. This reform has paid more attention to the relationship between good governance and the effectiveness of public investments [30]. Among the main actions, the support to employment and enterprises have partially played the role of economic stabilizers in place of the national investments, which have decreased in some regions by $40 \%$ from the pre-crisis period [31,32].

EU reforms have been adopted in Italy through the Action and Cohesion Plan (Piano di Azione e Coesione, PAC) by Delibera CIPE (Inter-ministerial Committee for Economic Planning) 1/2011. This strategy reallocated part of the Italian funding on specific countercyclical measures, the most important being the support to SMEs (Small and Medium Enterprises) [33], and to strategic economic sectors. Regional delays in the spending of the EU funds were evident in Southern and Insular regions, showing an average fund spending of only $7 \%$ of the total available funds in 2010 [34]. In order to accelerate regional expenditure of cohesion and structural funds, PAC provided some instruments, such as the introduction of timely planned spending objectives [35].

Accelerating the expenditure of Structural and Cohesion funds was felt as a necessity considering that the financial contribution related to the 2007-2013 Cohesion programme could be used only until the end of 2015. More precisely, 31 December 2015 has been the deadline for attributing the payments, made on the projects and operations by the beneficiaries, to the EU budget. In order to allow the completion of some "ongoing" or "not started" projects, the EU Commission has offered two possibilities.

1. The projects meeting certain requirements could be completed even by exploiting European resources allocated for the 2014-2020 Cohesion Programme. Such projects have been included in the 2014-2020 Regional Operative Programmes, and the National Operative Programmes, thus involving a mixed financial framework, consisting of both the 2007-2013 and the 2014-2020 resources.

2. The projects that did not meet such criteria could be completed by resorting to other financing means of the member state (national, regional, or local funding). The expenditure made until 31 December 2015 would have been considered eligible if the related project would have been effectively completed within a time limit (31 March 2017).

According to the European Commission Guidelines, some projects could keep being financed after the end of the Cohesion Programme: the so-called "Big Projects" (According to the EU regulation $\mathrm{n}$. $1083 / 2006$, "big projects" are investments whose cost is more than 50 million euros; these projects are characterized by a technical and economical indivisibility of the necessary works, and their approval lies with the EU Commission which supervises the progress of both the works and the financial transactions, in place of the Regions; http:/ / www.opencoesione.gov.it/) and a few others meeting definite criteria [36]. So, there are only some specific projects still being financed by the EU after the closing date. The rest of the public and private managers of the "on going" projects have lost the possibility of exploiting EU funds that have not been transferred by the EU to Italian Regions. Considering this is a complex situation, recently, economic literature has shown a deep interest in Cohesion policy impact on economic growth since it has become a countercyclical tool, being not anymore a simple instrument for promoting convergence $[37,38]$. However, there is no consensus in Structural funds' impact on economic growth. 
Rodriguez-Pose and Fratesi (2004) [39] noticed that, since the introduction of Structural and Cohesion funds, economic imbalances have remained relatively stable in the last years among European regions. This consideration takes a positive value given the economic crisis: so the stability of regional differences is considered as the main contribution of Cohesion policy.

Other researchers claim that the effects of ESIF (European Structural and Investment Funds) on economic growth have been positive but heterogeneous [40]. Dumciuvene et al. (2013) [41] argue over the inconsistent impact of cohesion policy on the main economic and social indicators. On the other hand, other scholars claim that the impact on the regional economy has been low [33,42], but statistically significant [43].

By analysing the relationship between Structural funds, growth, and occupation, Arcalean et al. (2012) [44] argue that Cohesion funds foster convergence between the poor and rich regions, by maximizing poor regional output and reducing the richest one, because of lower migration rates of skilled workers.

Jacoby (2014) [45] claims that until 2007 the EU Structural funds had a prominent role in promoting economic growth of European regions, in particular Eastern ones. However, after the beginning of the economic crisis, their counter-cyclical effect has been very weak, especially for non-euro zone areas.

Crescenzi (2009) [27] suggests that the lack of appreciable results by Cohesion policy is due to a non-optimal distribution of the related funds. Moreover, he claims that an increase of structural funds in more socio-economic disadvantaged areas should allow for more sustainable results, if it was accompanied by the reinforcement of their local governance.

Nowadays, a part of economic literature partially links the success of the investments realized through European funds to the regional managerial ability [46-48]. In fact, local administrations are the main stakeholders during the investment lifecycle, from the negotiation among the EU Commission, national, and regional governments, until project approval and funds distribution [10,49].

However, there has been a long debate on the role played by public institutions on economic development $[8,46,47,50]$.

Efendic et al. (2011) [51] find evidences of a partial positive and significant impact of institutions on output levels, even though they argue that the robustness of the analysis is partially related to the model specification choices.

Some scholars argue that Structural funds have had a greater impact in the South than in the Centre-North, but without reducing the gap in Italian productivity [6]. Some others eschew an idea of a uniform approach to regional development, recognizing the need to develop interventions tailored to the contexts and needs of specific countries [52] and regions [53,54].

Crescenzi et al. (2015) [8], assume that institutions play a strong conditioning role on the effectiveness of public investments in infrastructure, and that the quality of government affects the decisions and the returns of different types of investments. According to such studies there are evident divergences in public governance and in Cohesion funds management in the Italian regions, leading to different returns $[11,49,55]$.

Another part of literature has then explained the different roles of institutions on the investment returns by using several explanations. The performance of public institutions has been related to their geographical position [56]. Charron (2016) [57] has advanced the hypothesis that the heterogeneity in Structural Funds distribution to European Union regions depends on the interaction between regional formal institutions (the level of a regional autonomy), and informal institutions (its level of government quality). In case of low regional autonomy, member states and European Union level actors prefer to allocate greater levels of Funds to regions with a lower quality of government to increase cohesion.

\section{Preliminary Evidence}

In quantitative terms, in the 2007-2013 Cohesion Programme (The closing data of 2007-2013 funding program, 31 December 2013, did not correspond to the real deadline for implementation of co-financed projects, which has been 31 December 2015. Implementations continued for a 
two-year period, applying the current European rules about public balances: the so-called " +2 " rule. http:/ / opencoesione.gov.it) Italy has been the third major beneficiary of Cohesion policy having received 28 billion euro [58], only preceded by Poland (65 billion euro), and Spain (65 billion euro) [59].

We used data on the amount of funds available on Opencoesione databank, a governmental website providing information on cohesion policies in Italy. As established by the Strategic National Framework [58], during the 2007-2013 Program, European funds have been complemented by national funds, especially those allocated by the Inter-ministerial Committee for Economic Planning, and the Fund for Underused Areas.

In our analysis we refer to the investments realized both with the national and the European Funds within the Regional Operative Programs (ROPs) 2007-2013, excluding the National Operative Programmes (NOPs). This choice helped us in two different ways: (i) it reduced the proportion of infrastructural investments that are mainly managed through NOPs, and that produce economic returns on longer terms [21]; (ii) it reduced the influence of the national government, considering that ROPs reflect the independence of regions that select their priorities and financial instruments.

The projects that we considered in our analysis are only the ones having a start date recorded in the database. As a consequence, we have excluded all of the projects for which the database has neither received nor reported any beginning date yet.

Table 1 reports for each region the percentages of the allocated EU funds, the number of realized projects, the percentage of European funding on the ROP total value, and the percentage of funding that has not been expended or certified.

Table 1. Distribution of the European Union (EU) Cohesion funds, and related projects among Italian regions.

\begin{tabular}{ccccc}
\hline Region & $\begin{array}{c}\text { Regional } \\
\text { Fund/Total Funds }\end{array}$ & $\begin{array}{c}\text { N. Regional } \\
\text { Projects }\end{array}$ & $\begin{array}{c}\text { Average \% of European } \\
\text { Subsidy on the Total Cost }\end{array}$ & $\begin{array}{c}\text { Non-Expended } \\
\text { Funds }\end{array}$ \\
\hline Piedmont & $3.3 \%$ & 35.515 & $37.3 \%$ & $10.0 \%$ \\
Valle d'Aosta & $0.2 \%$ & 5.037 & $42.3 \%$ & $20.9 \%$ \\
Lombardy & $2.1 \%$ & 403.672 & $41.6 \%$ & $5.2 \%$ \\
Liguria & $1.6 \%$ & 19.264 & $31.7 \%$ & $14.9 \%$ \\
Trentino-Alto Adige & $0.9 \%$ & 7.463 & $30.9 \%$ & $16.2 \%$ \\
Friuli-Venezia Giulia & $0.9 \%$ & 51.152 & $34.5 \%$ & $9.3 \%$ \\
Veneto & $2.0 \%$ & 11.001 & $44.9 \%$ & $14.0 \%$ \\
Emilia Romagna & $2.2 \%$ & 19.143 & $31.9 \%$ & $19.6 \%$ \\
Tuscany & $3.2 \%$ & 62.835 & $50.2 \%$ & $12.6 \%$ \\
Umbria & $0.9 \%$ & 11.910 & $47.4 \%$ & $7.1 \%$ \\
Marche & $0.9 \%$ & 29.115 & $36.0 \%$ & $5.2 \%$ \\
Lazio & $3.3 \%$ & 13.096 & $49.7 \%$ & $20.5 \%$ \\
Abruzzo & $0.9 \%$ & 26.059 & $41.4 \%$ & $29.7 \%$ \\
Molise & $0.3 \%$ & 1.748 & $76.2 \%$ & $11.6 \%$ \\
Campania & $21.6 \%$ & 46.561 & $65.4 \%$ & $29.7 \%$ \\
Apulia & $18.3 \%$ & 68.438 & $64.3 \%$ & $20.0 \%$ \\
Basilicata & $1.7 \%$ & 10.183 & $39.9 \%$ & $60.1 \%$ \\
Calabria & $12.0 \%$ & 32.642 & $67.6 \%$ & $22.4 \%$ \\
Sicily & $19.8 \%$ & 44.575 & $47.9 \%$ & $37.3 \%$ \\
Sardinia & $3.8 \%$ & 20.157 & $45.1 \%$ & $17.3 \%$ \\
North & $13.2 \%$ & 552.247 & $37.4 \%$ & $13.8 \%$ \\
Centre & $8.3 \%$ & 116,956 & $55.1 \%$ & $11.4 \%$ \\
South and Islands & $78.4 \%$ & 250,363 & $58.9 \%$ & $28.5 \%$ \\
Convergence Objective & $73.4 \%$ & 202,399 & $59.9 \%$ & $28.8 \%$ \\
Italy & $100.0 \%$ & 919,566 & $54.9 \%$ & $19.2 \%$ \\
\hline
\end{tabular}

Our elaborations. Source: Opencoesione database.

Table 1 underlines the unequal distribution of EU funds among Italian regions, in accordance with European legislation. Five Southern regions belonging to the "Objective 1 Convergence" (Objective "Convergence" is addressed to those European regions whose per capita GDP is lower than the 75\% of European per capita GDP average investments related to the Objective Convergence, are the bulk of 
cohesion policy, attracting the $75 \%$ of all the ESIF Funds. The remaining $25 \%$ of EU funds are destined to investments aiming at the other two Objectives: "Regional Competitiveness and Employment" and "Territorial Cooperation".) have received the $73.4 \%$ of available funds. Campania is the Italian region that has obtained the largest amount of funds (21.6\%), followed by Sicily and Apulia. However, if we do not take into account the Objective Convergence regions, Lazio, Tuscany, and Piedmont are those having received the largest amount of resources (each with more than $3 \%$ of the total). Despite the relatively low amount of money received, Lombardy is the region that has approved the largest number of projects (equal to about $45 \%$ of total projects), followed by Apulia and Tuscany. On the contrary, Molise, Valle d'Aosta, and Trentino-Alto Adige are the ones that have financed the lowest number of interventions.

Moreover, the projects realized in Southern regions have had on average the highest subsidies from the EU. That means, for example, that Molise and Calabria projects have been financed for $65 \%$ by the EU funds, and for $35 \%$ by other national funds. On the contrary, investments in Trentino-Alto Adige consist of $35 \%$ EU structural funds, and of $65 \%$ national funds. On average, in Liguria and Toscana, only $31 \%$ of investments have been financed by EU.

Furthermore, with the exception of Valle d'Aosta and Lazio, in the Northern and Central regions more than the $80 \%$ of total Cohesion funds allocated for the 2007-2013 Program have been expended. Lombardy, Marche, Umbria, and Friuli-Venezia Giulia are the best Italian performers in terms of expenditure, without having expended only the $5-7 \%$ of their funds. The value of the non-expended funds in Southern and Insular regions are very heterogeneous: two regions (Molise and Sardinia) have not expended less than $20 \%$ of the funds allocated; and, the other four did not expend between $20 \%$ and $37 \%$ of funds (Campania, Puglia, Calabria and Sicilia). According to our data, the $60 \%$ of cohesion funds allocated in Basilicata have not been expended or have not been certified.

\section{Data Description}

In order to measure the quality of institutions, several indexes assessing local, economic, and political performances [60] have been generated. These include the World Governance Indicator [61], the Institutional Quality Index [14], and the European Quality of Government Index [62,63].

In our analysis we combined a set of indexes to measure the role of regional institutions' managerial capability on the economic growth in Italian regions: (i) Institutional Quality Index (IQI), by a weighted average of some social, political, and administrative indicators; (ii) a set of efficiency indexes elaborated on by us in order to assess regional managerial ability.

IQI is a composite index based on the World Governance Indicator, elaborated on by the World Bank [61]. Differently from the latter, which is focused on national level analysis, IQI refers to Italian regions (NUTS 2) and provinces (NUTS 3). It is calculated as a weighted average of 24 indicators (The 24 indicators used by IQI authors: Social Cooperatives, Associations, Election participation, Books published, Purchased in bookshop; Endowment of social facilities, Endowment of economic facilities, Regional health deficit, Separate waste collection, Urban environment index; Economic openness, Local government employees, Business density, Business mortality, Business environment; Crimes against properties, Crimes reported, Trial times, Magistrate productivity, Submerged economy, Tax evasion; Crimes against PS, Golden-Picci Index, and Special commissioners.), divided into five pillars combining institutional, social, and political aspects: (I) Voice and accountability; (II) Government effectiveness; (III) Regulatory quality; (IV) Rule of law; and, (V) Control and corruption. The IQI assumes values in a range from 0 (bad quality institutions) to 1 (high quality and efficient institutions).

Finally, in order to assess of the effectiveness and efficiency of public administration in managing Community funds, we referred to a set of three indexes on annual basis, elaborated on by using Opencoesione data (Online Opencoesione database classifies the co-financed projects, and the related funding, according to thirteen synthetic themes: 1. Digital Agenda; 2. Environment and risk prevention; 3. Cultural, natural, and touristic attraction; 4. Energy and energetic efficiency; 5 . Social Inclusion; 6. Education; 7. Employment and worker mobility; 8. PA Capacity building; 9. Research and 
Innovation; 10. Firm competitiveness; 11. Urban and rural renewal; 12. Services in the care for elderly and in childcare; and, 13. Transport and network infrastructure.) (According to the Opencoesione website, structural funds are expended through seven kinds of investments: 1 . Purchase of goods and services; 2 . Infrastructures; 3 . Incentives to firms; 4 . Contributions to people; 5 . Contributions to firms; 6. Provisions of capital; and, 7. Not available.): (i) the "Efficiency of Payments Index"; (ii) the "Financial Realization Index", obtained as the total payment made by regional authorities divided by the total amount of EU funds available on a regional level; and, (iii) the "Commitment Index", calculated as the total EU regional commitments divided by the total amount of EU funds available on a regional level.

The Efficiency of Payment Index measures the ability of local authorities to manage the projects and the funds that the European Union has allocated in each Italian Region during the 2007-2013 Program. It depends on the payments that the EU arranges for the regions, according to the progresses of financed projects. The index is calculated as a weighted average between the registered payments of each project, weighted with reference to its financial progress state (Opencoesione website defines the "Financial Progress State" of a project as the ratio between payments and public total funding, after the deduction of the other economies. A project can achieve four different results: "dismissed", meaning that the financial progress is more than $95 \%$; "ongoing", meaning that the financial progress is between $0 \%$ and $95 \%$; "not started", meaning that the financial progress is zero; "not applicable", meaning that financial progress is not available.); and, the total amounts of regional payments. In accordance with the values of a normal distribution, we used the three following weights: "dismissed", that project payments are weighted on a value of 0.975 ; "ongoing", where projects are on " 0.475 "; and, "not started", where projects on 0 . The index value range is $0-0.975$, where the highest value indicates that all of the approved projects of a Region have been completed, and the relative payments have been entirely arranged.

The "Commitment Index" measures the share of EU funds that each region declares to invest on the total of the funds provided by the EU.

The "Financial Realization Index" defines the ratio of the EU funding that has effectively been expended at the end of the Funding Program to the total of the funds.

Both of the indexes have a 0-1 range: the difference between the values of these two indexes explains how much it has been realized as compared to the value committed.

A negative value can be considered as an indicator of the inefficiency of the Italian regional administrators. In fact, we explained such results as an effect of the misuse or the late use of funds committed, or as a consequence of administrative delays that have slowed the beginning and the realization of the projects. The Financial Realization Index and the Commitment Index differ from the Efficiency of Payment index, being the latter an average score based on the data of each regional project, financial states, and progresses. The formers assess the overall financial situation of Italian regions, and the capacity of public administration to transfer EU funds to the beneficiaries during the European cohesion program. Table 2 describes the average value of the IQI, and of the three Indexes across the 20 Italian regions.

The gap between the North and the South of Italy, described by the main socio-economic indicators [3], is confirmed in our analysis by the three indexes. Among the considered indicators, there are strong differences in Italian regional assessments:

- the IQI index shows lower levels of institutional quality in the South-Island area, achieving scores of between 0.11 (Calabria) and 0.45 (Sardinia). Instead, a different scenario can be highlighted in the Centre and in the North, where the regions seem to be institutionally more virtuous, achieving scores ranging from 0.54 (Lombardy) to 0.88 (Tuscany);

- differently, the "Efficiency of Payments Index" presents a homogeneous situation with high values in projects realization. The only exception is Basilicata, in Southern areas, with the worst performers (0.396); 
- and, with reference to the Commitment Index, assessing the investment commitments, each region appears to have been righteous. The Financial Realization Index has lower levels than the Commitment Index, especially in Southern-Insular and Convergence areas. The difference between the declaration of commitments and the expenditure of the funds highlights the lack of complete expenditure planning. With the exception of Basilicata, whose value of commitment has entirely been expended, even if the value linked to the effective expenditure of the resources is the lowest at all, the other regions have expended less than the amount of resources they committed. The highest loss of EU resources is recorded in Abruzzo (-0.285), Campania (-0.285), and Sicily $(-0.227)$, while Marche $(-0.027)$, Liguria $(-0.031)$, and Friuli-Venezia Giulia $(-0.040)$ are the best performers.

Table 2. 2007-2015 Average of the Institutional Quality Index (IQI), the Efficiency of Payments Index, the Commitment Index, and the Financial Realization Index.

\begin{tabular}{cccccc}
\hline Region & IQI (A) & $\begin{array}{c}\text { Efficiency of } \\
\text { Payments Index (B) }\end{array}$ & $\begin{array}{c}\text { Commitment } \\
\text { Index (C) }\end{array}$ & $\begin{array}{c}\text { Financial Realization } \\
\text { Index (D) }\end{array}$ & (D)-C) \\
\hline Piedmont & 0.746 & 0.904 & 0.971 & 0.9 & -0.071 \\
Valle d'Aosta & 0.706 & 0.729 & 0.953 & 0.791 & -0.162 \\
Lombardy & 0.544 & 0.956 & 0.998 & 0.948 & -0.050 \\
Liguria & 0.735 & 0.911 & 0.884 & 0.851 & -0.033 \\
Trentino-Alto Adige & 0.857 & 0.893 & 0.901 & 0.838 & -0.063 \\
Friuli-Venezia Giulia & 0.724 & 0.906 & 0.948 & 0.907 & -0.041 \\
Veneto & 0.728 & 0.891 & 0.909 & 0.86 & -0.049 \\
Emilia Romagna & 0.723 & 0.835 & 0.961 & 0.804 & -0.157 \\
Tuscany & 0.885 & 0.841 & 0.987 & 0.874 & -0.113 \\
Umbria & 0.739 & 0.895 & 0.981 & 0.929 & -0.052 \\
Marche & 0.716 & 0.945 & 0.975 & 0.948 & -0.027 \\
Lazio & 0.67 & 0.815 & 0.889 & 0.795 & -0.094 \\
Abruzzo & 0.708 & 0.852 & 0.988 & 0.703 & -0.285 \\
Molise & 0.264 & 0.801 & 1 & 0.884 & -0.116 \\
Campania & 0.347 & 0.852 & 0.988 & 0.703 & -0.285 \\
Apulia & 0.435 & 0.766 & 0.99 & 0.8 & -0.190 \\
Basilicata & 0.425 & 0.396 & 0.399 & 0.399 & 0.000 \\
Calabria & 0.112 & 0.781 & 0.916 & 0.776 & -0.140 \\
Sicily & 0.237 & 0.718 & 0.854 & 0.627 & -0.227 \\
Sardinia & 0.458 & 0.859 & 0.898 & 0.827 & -0.071 \\
North & 0.720 & 0.878 & 0.941 & 0.862 & -0.078 \\
Centre & 0.766 & 0.879 & 0.976 & 0.889 & -0.087 \\
South and Islands & 0.373 & 0.753 & 0.879 & 0.715 & -0.164 \\
Convergence Objective & 0.311 & 0.703 & 0.829 & 0.661 & -0.168 \\
Italy & 0.588 & 0.827 & 0.920 & 0.808 & -0.111 \\
\hline
\end{tabular}

Our elaboration. Source: Opencoesione data.

As said, in fact, the missing exploitation of the Structural funds within the prescribed time limit leads to the loss of the European funding, with the exception of the so-called "Big Projects" and few other projects, with lower amounts. According to our data, during the 2007-2013 Programme, the EU Commission approved 95 projects whose costs were higher than 50 million euro each. As showed in Table 3, most of these projects (87) should have been realized in the Southern and Insular areas, and more precisely in the Objective Convergence regions (84). At a national level, these projects absorbed $21.88 \%$ of the total European and National funding: registering the highest levels in the Objective Convergence areas (27.99\%), and the lowest in Northern regions $(2.06 \%)$.

By the end of the Programmation, 46 Big Projects had been completed, while the other 49 were "ongoing" or "not started" projects, corresponding to $10.85 \%$ of the total funding invested during the 2007-2013 Programme. Among these investments, 48 were located in Southern and Insular Italy (only one in non-Objective Convergence Regions) amounting to the $13.72 \%$ of the total investment made in these areas. 
Such projects represent the majority of those eligible to receive new funding from the 2014-2020 Programme; while the rest of non-expended European funds have been lost and Regions cannot allocate them.

Table 3. Number of Big Projects (B.P); Share of dismissed and Not dismissed Big Projects; Share of funding on the total funding; and, Share of not dismissed B.P. funding on the total funding.

\begin{tabular}{cccccc}
\hline Macro-Areas & $\begin{array}{c}\text { No. of "Big } \\
\text { Projects" }\end{array}$ & $\begin{array}{c}\text { Dismissed } \\
\text { "B. P." }\end{array}$ & $\begin{array}{c}\text { Not Dismissed } \\
\text { B.P. }\end{array}$ & $\begin{array}{c}\text { Share of B.P. Funding } \\
\text { on the Total Funding }\end{array}$ & $\begin{array}{c}\text { Share of Not dismissed b.P. } \\
\text { Funding on the Total }\end{array}$ \\
\hline North & 3 & $100 \%$ & $0 \%$ & $2.06 \%$ & $0.00 \%$ \\
Centre & 5 & $80 \%$ & $20 \%$ & $6.74 \%$ & $1.18 \%$ \\
South & 87 & $45 \%$ & $55 \%$ & $26.86 \%$ & $13.72 \%$ \\
Ob. Convergence & 84 & $44 \%$ & $56 \%$ & $27.99 \%$ & $14.51 \%$ \\
Italy & 95 & $48 \%$ & $52 \%$ & $21.88 \%$ & $10.85 \%$ \\
\hline
\end{tabular}

Our elaboration. Source: Opencoesione data.

\section{Econometrical Analysis}

To evaluate both the role of local public administration efficiency in the expenditure of structural funds, and the impact of institutional quality on regional growth rates, the following panel data model, with the inclusion of fixed effects, has been estimated:

$$
\begin{aligned}
& \Delta y_{i t}=\beta_{1} \text { PagFin }_{i t}+\beta_{2} \text { QGov }_{i t}+\beta_{3} \text { EffPag }_{i t}+\beta_{4} \text { ImpFin }_{i t}+\beta_{5} \text { Coe } * \text { EffPag }_{i t} \\
& +\beta_{6} \operatorname{Coe} * Q_{\text {Gov }}+\beta_{7} X_{i t}+v_{i}+\varepsilon_{i t}
\end{aligned}
$$

where $\Delta y_{i t}$ is the annual growth rate of per capita GDP for each region i of the period 2007-2015. PagFin synthesizes the values of the financial realization index measuring the amount of the funds expended by each region on the total of those allocated by the EU, QGov indicates the IQI value of each region assessing the institution quality in Italian regions, EffPag is the value of the Efficiency payment index in evaluating the ability of local authorities to accomplish the projects and the related financial transactions, ImpFin stands for the value of Commitment Index taking into account the value of commitment provided by the regional policymakers for the Programming period.

Coe $* E f f P a g$ and Coe $* Q G o v$ are the two interaction terms: they test the hypothesis that the effect of a combined action of the two predictors is different than the sum of the individual effects. Such predictors are: Cohesion ( $\mathrm{Coe}$ ), representing the per capita amount of the payments made in each region, the Efficiency of Payment index, and the Quality of local institutions.

$\beta_{1}, \beta_{2}, \beta_{3}, \beta_{4}, \beta_{5}$, and $\beta_{6}$ are the coefficients that we estimate in order to assess the connection between the per capita GDP variation, and the four considered indexes.

$X_{i t}$ is a vector of the control variable that according to Rodriguez-Pose and Garcilazo (2013) [10], should affect regional economic performances (Table 2), while $\beta_{7}$ represents the related vector of coefficients.

The hypothesis of a positive impact of the variables on the economic growth will be verified if $\beta_{1}>0, \beta_{2}>0, \beta_{3}>0, \beta_{4}>0, \beta_{5}>0$, and $\beta_{6}>0$.

The chosen control variables estimate that the level of Human Capital in the region, namely (log of) the percentage of adults having either only completed primary school (prim_educ) or holding a university degree (tert_educ), the Infrastructural Endowment (infr_den), (log of) motorway kilometers by the total population, the Employment Rate (emp_rate), and the agglomeration effects on local economies (through Employment Density (emp_den), namely the (log of) number of employed people per square kilometers, and the Population Density (pop_den), which is the (log of) population per square kilometer).

Lastly, $v_{i t}$ is the regional level effect, while $\varepsilon_{i t}$ is the disturbance term.

Fixed effect estimation strategy $(\mathrm{FE})$ has been induced by the correlation between the $\mathrm{X}$ vector of control variables and the regional level effect $\left(v_{i t}\right)$. FE strategy considers $v_{i t}$ as another parameter 
that has to be estimated (Baum, 2006), and suppose orthogonality between the regressors and the disturbance term $\left(\varepsilon_{i t}\right)$.

On the contrary, the model can be estimated through Random Effect estimation strategy (RE), in case the regional level effect $\left(v_{i t}\right)$ is supposed not to be correlated with the control variables, and the $v_{i t}$ can be estimated considering it as additional random disturbances. This additional orthogonality condition is identifiable as an overidentifying restriction.

After running either an FE or RE analysis, taking into account heteroschedasticity-robust standard errors, the Hausman test (Prob > chi2 $=0.00000-$ chi2 $=45.67)$, and the Breusch Pagan statistic $(0.002)$ that allowed us to reject the hypothesis of correlation between the error term and the regressors. Moreover, recognizing that there is the likelihood of endogeneity of the data, the aim of the paper is looking for ceteris paribus correlation.

To control for endogeneity, one-period lagged independent variables are specified to create an overlapped space between fiscal policies and compound growth of GDP in the subsequence periods. This is the standard approach to deal with endogeneity [61-67].

The total sample considered consisted of 20 Italian regions, covering the years between 2007 and 2015, overlapping the 2007-2013 Funding Program (The closing data of 2007-2013 funding program, 31 December 2013, does not correspond to the real deadline for implementation of co-financed projects, which is 31 December 2015. Implementations continued for an additional two-year period, applying the current European rules about public balances: the so-called "+2" rule; http:/ / opencoesione.gov.it), and the Great Recession. As said, we limited the analysis to the funds related to the Regional Operative Programs (ROP), excluding the National Operation Programs (NOP), and to the projects whose start date was recorded in the governmental database by 31 October 2016.

In our model specification, we have used a two-way fixed effects panel regression model (Hausmann test has confirmed the goodness of the choice of the used model), with a robust heteroschedasticity estimator, and with region and time control.

This empirical model has been estimated by minimizing the autocorrelation effect through the introduction of lagged variables: in this way, we have considered neighboring region interaction and minimized these effects on the residuals. Moran's I test confirms the lack of spatial autocorrelation on the residuals.

\section{Results}

In our first estimation, we took into account the Cohesion expenditure levels of 20 Italian regions (Table 2). We used different specifications in order to examine the relation between regional economic growth and different variables: the financial realization level (the total EU payments made by regional authorities divided by the total amount of EU funds available on a regional level) (Model 1); institutional quality (IQI) (Model 2); the previous variables analyzed simultaneously (Model 3); the previous variables, the efficiency of payments and the commitment index (the total commitments made by regional authorities divided by the total amount of EU funds available on a regional level) (Model 4); the interaction of payment efficiency and government quality with the amount of expended funds (Model 5); finally, all of the variables simultaneously (Model 6). The GDP per capita of the previous year has been taken into account in all six models.

As showed in Table 4, the first model estimated on twenty regions highlights a statistically significant correlation between regional growth and the total amount of funding allocated through European cohesion policy and national funds.

As we expected, the financial realization level (payments-to-funding ratio) has a positive and significant effect on regional per capita GDP growth, except that in Model 3. Furthermore, the Commitment Index is positive again, but is not statistically significant.

The relationship between regional growth and the quality of regional institutions is positive and statistically significant, except that in Model 6, where it is positive but not significant. 
The overall financial state of the projects (Efficiency of Payments) has no significant impact on regional growth, being positive in a model (Model 6), and negative in another (Model 4). In our opinion, this indicates that the impact of completion time on economic growth is more minor than the capability of allocating the total amount.

The two interaction terms, showing the measure in which public investment returns depend on regional government ability, are both positive in Models 5 and 6, being significant in the first. This suggests that high levels of expenditure, accompanied both by an improvement of regional institution quality and by payment efficiency produce a significant impact on regional GDP.

As for the previous variables, the analysis of control variables confirms the expected results.

Table 4. Impact of Structural and Cohesion investments on regional economic growth. Dependent Variable: GDP per capita growth rate.

\begin{tabular}{|c|c|c|c|c|c|c|}
\hline & Model 1 & Model 2 & Model 3 & Model 4 & Model 5 & Model 6 \\
\hline yi_1 & $0.1392^{* * *}(0.0375)$ & $0.1383^{* * *}(0.0339)$ & $0.1161^{* * *}(0.0362)$ & $0.2057^{* * *}(0.0430)$ & $0.1231^{* * *}(0.0374)$ & $0.1634^{* * *}(0.0423)$ \\
\hline pag_fin & $0.0522 *(0.0294)$ & & $0.0386(0.0433)$ & $0.1032 * *(0.0436)$ & & $0.1043^{* *}(0.0502)$ \\
\hline q_gov & & $0.0830 * *(0.0369)$ & $0.0669 *(0.0351)$ & $0.0939 * *(0.0477)$ & & $0.1601(0.1774)$ \\
\hline imp_fin & & & & $0.0079(0.0204)$ & & $0.0149(0.0245)$ \\
\hline Coe_Effpag & & & & & $0.0187 *(0.0103)$ & $0.0139(0.1313)$ \\
\hline Coe_Qgov & & & & & $0.0600 *(0.0313)$ & $-0.0741(0.1662)$ \\
\hline infr_den & $-0.0059(0.0082)$ & $-0.0031(0.0059)$ & $-0.0034(0.0074)$ & $-0.0069(0.0098)$ & $-0.0026(0.0061)$ & $-0.0036(0.0087)$ \\
\hline emp_rate & $0.0063^{* * *}(0.0016)$ & $0.0069^{* * *}(0.0013)$ & $0.0060 * * *(0.0011)$ & $0.0070^{* * *}(0.0016)$ & $0.0072^{* * *}(0.0015)$ & $0.0072^{* * *}(0.0017)$ \\
\hline & $-0.5197^{* * *}$ & $-0.6700^{* * *}$ & $-0.5697^{* * *}$ & $-0.7678^{* * *}$ & $-0.6330^{* * *}$ & $-0.7253^{* * *}$ \\
\hline emp_den & $(0.1154)$ & $(0.1147)$ & $(0.1034)$ & $(0.1244)$ & $(0.1048)$ & $(0.1323)$ \\
\hline pop_den & $0.5185^{* * *}(0.1152)$ & $0.6651^{* * *}(0.1158)$ & $0.5655^{* * *}(0.1038)$ & $0.7618^{* * *}(0.1253)$ & $0.6295^{* * *}(0.1050)$ & $0.7210^{* * *}(0.1335)$ \\
\hline$N$ & 129 & 114 & 111 & 109 & 110 & 109 \\
\hline
\end{tabular}

Robust standards errors in parenthesis: ${ }^{* * *} p<0.01 ;{ }^{* *} p<0.05 ;{ }^{*} p<0.1$.

The two agglomeration variables have a significant relation with the economic growth: employment density affects negatively GDP variations, differently from the positive effect of population density. In the same way, an increase in the number of employed people affects positively regional economic growth.

A higher percentage of population having achieved, at least, a primary school education influences positively and significantly (Models 1 and 5) the economic growth. On the contrary, tertiary education seems not a significant variable in strengthening the economic growth, as well as the infrastructural endowment.

Once we considered the whole territory, we decided to focus our analysis on the other two samples, in order to verify if the EU policy has obtained the declared result of reducing imbalances: (i) the regions belonging to the Southern and Insular Italy (Table 5) (Abruzzo, Molise, Campania, Apulia, Basilicata, Calabria, Sicily, and Sardinia); and, (ii) in particular on "Objective Convergence regions" (Table 6) (Campania, Apulia, Basilicata, Calabria and Sicily).

The first sample considers the disadvantaged regions by taking into account the historical gap dividing Italy, while the second one takes it into account from a EU perspective.

These regions suffer from an historical economic delay compared to the Central and Northern Italian regions, which has increased since the '70s [68]. At the beginning of the Great Recession, the reduction of international trade has mostly damaged the Northern regions, but thanks to their competitive advantage, these have been able to recover the economic performances faster than the other regions: in 2013, the GDP in Southern regions and Islands was 13.5\% lower than 2007, while in Central and Northern regions it was on average only $7 \%$ lower [3]. Due to their structural problems, Southern regions suffered the effects of the economic crisis longer than the others: Southern regions GDP have begun to grow again only in 2015 [3]. 
Table 5. Impact of structural and cohesion investments on economic growth of Southern and Insular Regions. Dependent Variable: GDP per capita growth rate.

\begin{tabular}{|c|c|c|c|c|c|c|}
\hline & Model 1 & Model 2 & Model 3 & Model 4 & Model 5 & Model 6 \\
\hline yi_1 & $0.1468(0.0864)$ & $0.3427^{* * *}(0.0963)$ & $0.3868^{* * *}(0.0915)$ & $0.2089 *(0.0837)$ & $0.2639 * *(0.0533)$ & $0.2265 *(0.0953)$ \\
\hline pag_fin & $0.0380(0.0686)$ & & $0.0799(0.0466)$ & $0.1390 * *(0.0534)$ & & $0.0758(0.0513)$ \\
\hline q_gov & & $0.2067^{* * *}(0.0522)$ & $0.2059 * * *(0.0448)$ & $0.0907(0.0720)$ & & $0.7065(0.3531)$ \\
\hline eff_pag & & & & $0.0128(0.0161)$ & & $0.2390(0.1893)$ \\
\hline imp_fin & & & & $0.0201(0.0237)$ & & $0.0071(0.0165)$ \\
\hline Coe_Effpag2 & & & & & $0.0108(0.0152)$ & $-0.2218(0.1954)$ \\
\hline Coe_Qgov2 & & & & & $0.1395^{* * *}(0.0243)$ & $0.7744(0.3674)$ \\
\hline tert_educ & $-0.0590(0.1487)$ & $0.1371 *(0.1167)$ & $0.1202(0.1510)$ & $-0.0520(0.1560)$ & & $-0.0811(0.1788)$ \\
\hline prim_educ & $0.0505(0.1481)$ & $0.3811^{* * *}(0.1518)$ & $0.3743^{* * *}(0.1825)$ & $0.1460(0.2065)$ & $0.2230 * * *(0.0193)$ & $0.1110(0.2363)$ \\
\hline infr_den & $0.0126(0.0166)$ & $0.0264^{* * *}(0.0059)$ & $0.0297^{* * *}(0.0057)$ & $0.0402 * * *(0.0089)$ & $0.0328^{* * *}(0.0055)$ & $0.0375^{* * *}(0.0128)$ \\
\hline emp_rate & $0.0088^{* * *}(0.0030)$ & $0.0000(0.0041)$ & $-0.0010(0.0046)$ & $0.0050(0.0029)$ & $0.0028(0.0034)$ & $0.0046(0.0035)$ \\
\hline emp_den & $\begin{array}{c}-0.5858^{* * *} \\
(0.1133)\end{array}$ & $\begin{array}{c}-0.8236^{* * *} \\
(0.2407)\end{array}$ & $\begin{array}{c}-0.8330^{* * *} \\
(0.2357)\end{array}$ & $\begin{array}{c}-0.6712^{* * *} \\
(0.2503)\end{array}$ & $\begin{array}{c}-0.6939^{* * *} \\
(0.2004)\end{array}$ & $\begin{array}{c}-0.5684^{* * *} \\
(0.2738)\end{array}$ \\
\hline pop_den & $0.5895^{* * *}(0.1118)$ & $0.8054^{* * *}(0.2411)$ & $0.8098 * * *(0.2377)$ & $0.6652 * * *(0.2448)$ & $0.6820^{* * *}(0.1963)$ & $0.5689^{* * *}(0.2654)$ \\
\hline$N$ & 45 & 42 & 39 & 37 & 38 & 37 \\
\hline$R^{2}$ & 0.55 & 0.588 & 0.58 & 0.62 & 0.57 & 0.67 \\
\hline Waldchi2 & 28.15 & 49.43 & 43.94 & 57.95 & 47.26 & 66.16 \\
\hline$p$-value & 0.0004 & 0.000 & 0.000 & 0.000 & 0.000 & 0.000 \\
\hline F-statistics & 9.070 .000 & 11.22 & 9.62 & 6.280 .0003 & 8.21 & 4.76 \\
\hline
\end{tabular}

Table 6. Impact of structural and cohesion investments on economic growth of Convergence Regions. Dependent Variable: GDP per capita growth rate.

\begin{tabular}{|c|c|c|c|c|c|c|}
\hline & Model 1 & Model 2 & Model 3 & Model 4 & Model 5 & Model 6 \\
\hline yi_1 & $0.3407^{* *}(0.1090)$ & $0.3685^{* * *}(0.1017)$ & $0.4776^{* * *}(0.0800)$ & $0.4214 *(0.1481)$ & $0.0561(0.1249)$ & $0.3585 *(0.1014)$ \\
\hline pag_fin & $0.1062(0.0664)$ & & $0.1037 *(0.0653)$ & $0.1309^{* *}(0.0306)$ & & $0.0582(0.0340)$ \\
\hline eff_pag & & & & $-0.0035(0.0287)$ & & $0.4371^{* * *}(0.1123)$ \\
\hline imp_fin & & & & $0.0374(0.0222)$ & & $0.0163(0.0109)$ \\
\hline Coe_Qgov & & & & & $0.1170(0.0752)$ & $1.1189^{* * *}(0.2045)$ \\
\hline tert_educ & $0.1339 *(0.1427)$ & $0.2316^{* * *}(0.0533)$ & $0.2436^{* * *}(0.0812)$ & $0.1640(0.0852)$ & & $0.1362(0.0452)$ \\
\hline prim_educ & $0.2237(0.2026)$ & $0.4971^{* * *}(0.1068)$ & $0.3808^{* * *}(0.0941)$ & $0.3474^{* *}(0.1210)$ & $0.2976^{* *}(0.1142)$ & $0.3574^{* * *}(0.1436)$ \\
\hline infr_den & $0.0156(0.0306)$ & $0.0279(0.0176)$ & $0.0497^{* *}(0.0202)$ & $0.0570 * *(0.0110)$ & $0.0116(0.0208)$ & $0.0420 *(0.0114)$ \\
\hline pop_den & $0.5355^{* * *}(0.1959)$ & $0.8013^{* * *}(0.2162)$ & $0.5899 * * *(0.2108)$ & $0.6709^{* * *}(0.2370)$ & $0.8112^{* * *}(0.2851)$ & $0.5925^{* * *}(0.1545)$ \\
\hline$N$ & 31 & 30 & 27 & 25 & 26 & 25 \\
\hline$R^{2}$ & 0.48 & 0.60 & 0.688 & 0.63 & 0.46 & 0.8080 \\
\hline Wald chi2 & 19.54 & 31.53 & 33.63 & 36.95 & 19.70 & 68.89 \\
\hline$p$-value & 0.0122 & 0.0001 & 0.0001 & 0.0001 & 0.0116 & 0.000 \\
\hline F-statistics & 3.64 & 6.200 .0008 & 7.910 .0005 & 5.98 & 2.92 & 4.84 \\
\hline
\end{tabular}

According to the National Institute of Statistics, in 2014 the per capita GDP of Southern regions was $44 \%$ lower than the Central and Northern ones, thus underlining the persistence of strong economic and social imbalances among Italian regions. Apart from the economic problems, Southern and Insular regions are still affected by structural problems, mostly related to high unemployment rates, political, social, and infrastructural delays [1]. 
The evidences from the second model are lightly different from the previous ones.

Model 2, Table 5, shows a positive and very significant relationship between the quality of government, and the regional per capita GDP growth rate in two of the five models (Models 2 and 3), underlining that an improvement of regional institution quality could grant better economic results. The Efficiency of Payment index and the Commitment Index do not have a significant impact on the economic growth of these regions.

With regard to the control variables, we found that the two variables summarizing data on education have the same impact than in the previous model. The presence of population with a primary level of education affects economic growth positively; such impact is significant according to Models 2, 3, and 5. Tertiary education does not have a significant impact on regional per capita GDP, with the exception of Model 2, in which it has a positive and significant effect.

Also, variables measuring agglomeration effects have the same impact as in the first model, the coefficient measuring the effects of employment density is negative, while that measuring population density is positive, but both of them are significant in all six models.

The effect of employment rate is positive in five models, but it is significant only in one case (Model 1).

The only exception is the infrastructural density that has a result of positive and highly significant, which differs from the analysis conducted on the whole of Italy. According to the National Institute of Statistics, in our opinion, this result highlights the underdevelopment of the infrastructural endowment of this area, and the necessity of improving transport networks.

The Model 3 (Table 6) is based on the five Objective Convergence regions.

The results of the third model show that our Financial Realization Index has a positive relationship with the per capita GDP growth rate, being statistically significant in two models (Models 3 and 4). Quality of government is a key determinant of economic growth in these five regions, being positive and significant in all the estimations.

Furthermore, despite being negative and not significant in Model 4, the Efficiency of Payments has a positive and significant impact on growth in Model 6, considering all of the independent variables.

On the contrary, the Commitment Index is positive but not significant in Models 4 and 6.

In the same way, despite being positive in Model 5, the two interaction terms are positive and highly significant in the last model estimated. These results show that an increase in Structural and Cohesion funds expenditure, combined with the improvement of regional institutional quality and of payment efficiency, would lead to higher returns from regional investments made through structural and cohesion funds.

We noticed the positive and mainly significant relationship existing between the growth rates and the selected control variables in the Convergence regions, apart from employment density, whose effects are significant but negative.

The impact of the selected variables is more or less the same in the three models that we estimated. The Institutional Quality has a positive and significant relationship with the economic returns of the EU-funded investments in the three analysed geographic areas, as well as the Financial Realization Index. The efficiency of Payment, and the Commitment Index are not key determinants of growth for regional economies, but the former assumes significant and positive values when we take into account only the Objective Convergence Regions. These results highlight the necessity to improve the capability of regional policymakers in these areas to administer the Structural Funds projects. Interaction terms are positive in all three models but they are significant especially in Objective Convergence regions, where an improvement in the Efficiency of Payment and in the Quality of government would produce the best results, if it is accompanied by a good level of expenditure.

\section{Conclusions}

Despite the widespread attention paid to the role of institutional context in terms of social and economic implications, the effects of Structural funds management by local administrations seems 
to be an unexplored topic. Numerous empirical analyses have tried to find clear evidences on the effective mediating role that government quality has on investment returns. However, no solid support has been given to the hypothesis that regions with efficient institutions could easily achieve economic and developmental advantages through Structural and Cohesion funds [46].

We have tried to correct these deficiencies when analyzing the relationship between regional growth rates and the returns of EU Cohesion investments, the quality of regional government, and its ability of managing European regional funds.

In order to assess the role of policymakers in fostering local growth through cohesion expenditure, we referred to two kind of indexes: the Institutional Quality Index [14], and a set of indexes assessing the efficiency of regional administrations in terms of spending power. The descriptive analysis demonstrated that Italy is divided into two parts: Northern regions reaching the highest levels of institutional quality and managerial ability in funds expenditure, and the Southern ones, who, on the contrary achieved the lowest scores in terms of IQI and lower levels of financial realization and efficiency of payments.

Based on a panel data model for the years between 2007 and 2015, our models unveiled that local government quality is a key determinant for investment returns across the Italian regions and it has a higher impact than the efficiency of payments. This result changes when the model is applied to Southern and Insular Regions, underlining the fundamental impact of efficiency on investments in those regions suffering from structural delays.

Moreover, an increasing of efficiency of payments, combined with good levels of expenditure would produce better results in Southern and Insular regions, and especially in Convergence Regions. This underlines the current incapability of these regions to manage such large amounts of structural funds, and the necessity to improve their managerial ability. The significance of the last model including all of the variables, shows that an improvement in institutional quality, together with a better financial realization and an acceleration of payments, would produce the better results in Convergence regions, namely the poorest ones, than in the rest of the country. Furthermore, if this improvement will be accompanied by strong structural investments in education, infrastructures, and employment, it should give a strong contribution to the economic growth of this undeveloped area.

The historical context taken into account highlights the importance of the previous factors: in fact, the Great Recession imposed strong limits to national and regional spending power, causing a major use of structural and cohesion funds in order to self-sustain [32]. During the economic and financial crisis, the necessity of making bureaucracy and public institutions more efficient has become a pillar in the European political agenda [69].

Author Contributions: Arbolino R. and Boffardi R. conceived and designed the experiments; Arbolino R. performed the experiments; Arbolino R. and Boffardi R. analyzed the data; Boffardi R. contributed reagents/materials/analysis tools; Arbolino R. and Boffardi R. wrote the paper.

Conflicts of Interest: The authors declare no conflict of interest.

\section{References}

1. ISTAT. Rapporto Annuale 2017; La situazione del Paese; Centro Astalli: Rome, Italy, 2017.

2. Arbolino, R.; Carlucci, F.; Cirà, A.; Ioppolo, G.; Yigitcanlar, T. Efficiency of the EU regulation on greenhouse gas emissions in Italy: The hierarchical cluster analysis approach. Ecol. Indicat. 2017, 81, 115-123. [CrossRef]

3. Banca d'Italia Economie Regionali. L'economia Delle Regioni Italiane. Dinamiche Recenti e Aspetti Strutturali, Numero 43; Banca D'italia Eurosistema: Roma, Italy, 2016.

4. Becker, O.S.; Egger, P.H.; Ehrlich, M. Too much of a good thing? On the growth effects of the EU's regional policy. Eur. Econ. Rev. 2012, 56, 648-668. [CrossRef]

5. EU Commission. EU Cohesion Policy Contributing to Employment and Growth in Europe; EU Commission: Brussels, Belgium, 2013.

6. Aiello, F.; Pupo, V. Structural funds and the economic divide in Italy. J. Policy Model. 2012, 34, $403-418$. [CrossRef] 
7. Rodríguez-Pose, A.; Fratesi, U. Regional business cycles and the emergence of sheltered economies in the southern periphery of Europe. Growth Chang. 2007, 38, 621-648. [CrossRef]

8. Crescenzi, R.; Cataldo, M.; Rodriguez-Pose, A. Government quality and the economic returns of transport infrastructure investment in European regions. Reg. Sci. 2016, 56, 555-582. [CrossRef]

9. Baudner, J.; Bull, M.J. The Europeanisation of national institutions reassessed: A comparison of regional policies in Germany and Italy. Comp. Eur. Politics 2013, 11, 201-221. [CrossRef]

10. Rodriguez-Pose, A.; Garcilazo, E. Quality of Government and the Returns of Investment. Examining the Impact of Cohesion Expenditure in European Regions; OECD Regional Development Working Papers; OECD Publishing: Paris, France, 2013.

11. Milio, S. Can administrative capacity explain differences in regional performances? Evidence from structural funds implementation in southern Italy. Reg. Stud. 2007, 41, 429-442. [CrossRef]

12. Bruinshoofd, A. Institutional Quality and Economic Performance. Available online: https://economics. rabobank.com/publications/2016/january/institutional-quality-and-economic-performance/ (accessed on 5 August 2017).

13. EU Commission. Investment for Jobs and Growth: Promoting Development and Good Governance in EU Regions and Cities; Sixth Report on Economic, Social and Territorial Cohesion; Publications Office of the European Union: Luxembourg, 2014.

14. Nifo, A.; Vecchione, G. Measuring Institutional Quality in Italy. Riv. Econ. Mezzog. 2015, 29, 157-182.

15. Buchanan, B.G.; Le, V.Q.; Rishi, M. Foreign direct investment and institutional quality: Some empirical evidence. Int. Rev. Financ. Anal. 2012, 21, 81-89. [CrossRef]

16. Mitze, T.; Matze, F. Public debt and growth in German federal states:What can Europe learn? J. Policy Model. 2015, 37, 208-228. [CrossRef]

17. Lago-Penas, S.; Ventelou, B. The effects of regional sizing on growth. Public Choice 2006, 127, 415-435. [CrossRef]

18. Srithongrung, A.; Sánchez-Juárez, I. Fiscal Policies and Subnational Economic Growth in Mexico. Int. J. Econ. Financ. Issues 2015, 5, 11-22.

19. Coetzee, C.E.; Kleynhans, E.P.J. The contribution of public capital towards economic growth: A KwaZulu-Natal case study. S. Afr. J. Econ. Manag. Sci. 2017, 20, 1015-8812. [CrossRef]

20. Auteri, M.; Costantini, M. Fiscal Policy and Economic Growth: The Case of the Italian Regions. Rev. Reg. Stud. 2004, 34, 72-94.

21. Kyriacou, A.; Roca-Sagalés, O. The impact of EU structural funds on regional disparities within member states. Environ. Plan. C Gov. Policy 2012. [CrossRef]

22. European Council. Council Regulation (EC) No 1083/2006 of 11 July 2006 Laying down General Provisions on the European Regional Development Fund, the European Social Fund and the Cohesion Fund and Repealing Regulation (EC) No 1260/1999; Council of the European Union: Brussels, Belgium, 2006.

23. Formez, P.A. Guida alle Opportunità di finanziamento DELL'UNIONE Europea 2014-2020; European Union: Brussels, Belgium, 2014.

24. Mohl, P.; Hagen, T. Do EU structural funds promote regional growth? New evidence from various panel data approaches. Reg. Sci. Urban Econ. 2010, 40, 353-365. [CrossRef]

25. Commission of the European Communities. A New Partnership for Cohesion: Convergence, Competitiveness, Cooperation; Third Report on Economic and Social Cohesion; Office for Official Publications of the European Communities: Luxembourg, 2004.

26. Wamser, G.; Woon Nam, C.; Schoenberg, A. The Lisbon Agenda and Innovation-oriented Cohesion Policy: A New Challenge for Economic Integration among the EU Regions. J. Econ. Integr. 2013, 28, 37-58. [CrossRef]

27. Crescenzi, R. Undermining the principle of concentration? European Union regional policy and the socio-economic disadvantage of European regions. Reg. Stud. 2009, 43, 111-133. [CrossRef]

28. EU Commission. Communication from the European Commission to the European Council-A European Economic Recovery Plan; EU Commission: Brussels, Belgium, 2008.

29. EU Commission. Road to Recovery: The Cohesion Package-Question and Answers on the Contribution of Cohesion Policy to the European Economic Recovery Plan; MEMO/08/740; EU Commission: Brussels, Belgium, 2008.

30. Barca, F. Un'agenda per la Riforma Della Politica di Coesione, Una Politica di Svilupporivoltaailuoghi per Rispondere Alle Sfide e Alle Aspettative Dell'unione Europea; Dipartimento per lo Sviluppo e la Coesione Economica; European Union: Brussels, Belgium, 2009. 
31. Bachtler, J.; Mendez, C. EU Cohesion Policy and European Integration: The Dynamics of EU Budget and Regional Policy Reform; Ashgate Publishing, Ltd.: Farnham, UK, 2016.

32. Berkowitz, P.; Von Breska, E.; Pieńkowski, J.; Catalina, R.A. The Impact of the Economic and Financial Crisis on the Reform of Cohesion Policy 2008-2013; Regional Working Paper; EU Commission: Brussels, Belgium, 2015.

33. Ciani, E.; De Blasio, G. European Structural Funds during the Crisis: Evidence from Southern Italy; Working Papers Banca d'Italia, N. In Proceedings of the 55th Congress of the European Regional Science Association: "World Renaissance: Changing roles for people and places", Lisbon, Portugal, 25-28 August 2015.

34. Camera Deideputati. I Temi Dell'attività Parlamentare Nella XVI Legislatura, Politiche di Coesioneterritoriale, No 1/26, 2013. Available online: http:/ / www.camera.it/temiap/leg16/leg17.temi16.area-26 (accessed on 5 August 2017).

35. Agenzia per la Coesione Territoriale, Obiettivi del Piano di Azione e Coesione, 2011. Available online: http://www.agenziacoesione.gov.it/it/politiche_e_attivita/piano_di_Azione_Coesione/ (accessed on 5 August 2017).

36. European Commission. ALLEGATO Della Decisione Della Commissione che Modifica la Decisione C(2013)1573 Sull'approvazione Degli Orientamenti Sulla Chiusura dei Programmi Operativi Adottatiper Beneficiare Dell'assistenza del Fondo Europeo di Sviluppo Regionale, del Fondo Sociale Europeo e del Fondo di Coesione (2007-2013); Bruxelles, 30.4.2015 C(2015) 2771 final ANNEX 1; European Commission: Brussels, Belgium, 2015.

37. Kutan, A.M.; Yigit, T.M. European integration, productivity growth and real convergence. Eur. Econ. Rev. 2007, 51, 1370-1395. [CrossRef]

38. Archibugi, D.; Filippetti, A. Is the Economic Crisis Impairing Convergence in Innovation Performance across Europe. J. Common Mark. Stud. 2011, 49, 1153-1182. [CrossRef]

39. Rodriguez-Pose, A.; Fratesi, U. Between Development and Social Policies: The Impact of European Structural Funds in Objective 1 Regions. Reg. Stud. 2004, 38, 97-113. [CrossRef]

40. Cappelen, A.; Castellacci, F.; Fagerberg, J.; Verspagen, B. The Impact of EU Regional Support on Growth and Convergence in the European Union. J. Common Mark. Stud. 2003, 41, 621-644. [CrossRef]

41. Dumciuvene, D.; Stundziene, A.; Startiene, G. Relationship between Structural Funds and Economic Indicator of the European Union. Inzinerine Ekon. Eng. Econ. 2016, 26, 507-516.

42. Le Gallo, J.; Dall'erba, S.; Guillain, R. The Local versus Global Dilemma of the Effects of Structural Funds. Growth Chang. 2011, 42, 466-490. [CrossRef]

43. Coppola, G.; Destefanis, S. Structural Funds and Regional Convergence: Some Sectoral Estimates for Italy. In Geographical Labor Markets Imbalances; AIEL Series in Labour Economics; Springer: Berlin/Heidelberg, Germany, 2015; pp. 307-333.

44. Arcalean, C.; Glomm, G.; Schiopu, I. Growth Effects of spatial redistribution policies. J. Econ. Dyn. Control 2012, 136, 988-1008. [CrossRef]

45. Jacoby, W. The EU Factor in Fat Times and in Lean: Did the EU Amplify the Boom and Soften the Bust? J. Mark. Stud. 2014, 52, 52-70. [CrossRef]

46. Rodriguez-Pose, A. Do Institutions Matter for Regional Development? Reg. Stud. 2013, 47, $1034-1047$. [CrossRef]

47. Van Den Broek, J.; Smulders, H. The evolution of a cross-border regional innovation system: An institutional perspective. In Proceedings of the Regional Studies Association European Conference, Tampere, Finland, 5-8 May 2013.

48. Agovino, M.; Casaccia, M.; Crociata, A. Effectiveness and efficiency of European Regional Development Fund on separate waste collection: evidence from Italian regions by a stochastic frontier approach. Econ. Polit. 2016. [CrossRef]

49. Dellmuth, L.M.; Schraff, D.; Stoffel, M.F. Distributive Politics, Electoral Institutions and European Structural and Investment Funding: Evidence from Italy and France. J. Common Mark. Stud. 2017, 55, 275-293. [CrossRef]

50. Lasagni, A.; Nifo, A.; Vecchione, G. Firm Productivity and Institutional Quality. Evidence from Italian Industry. J. Reg. Sci. 2015. [CrossRef]

51. Efendic, A.; Pugh, G.; Adnett, N. Institutions and economic performance: A meta-regression analysis. Eur. J. Political Econ. 2011, 27, 586-599. [CrossRef]

52. Pereira, A.M.; Gaspar, V. An intertemporal Analysis of development policies in the EU. J. Policy Model. 1999, 21, 799-822. [CrossRef] 
53. Farole, T.; Rodríguez-Pose, A.; Storper, M. Cohesion policy in the European Union: Growth, geography, institutions. JCMS 2011, 49, 1089-1111. [CrossRef]

54. Romero, I.; Fernández-Serrano, J. The European Cohesion policy and the promotion of entrepreneurship. The case of Andalusia. Investig. Reg. 2014, 29, 215-236.

55. Terracciano, B.; Graziano, P.R. EU Cohesion Policy Implementation and Administrative Capacities: Insights from Italian Regions. Reg. Fed. Stud. 2016. [CrossRef]

56. Ketterer, T.D.; Rodríguez-Pose, A. Institutions vs. 'first-nature' geography: What drives economic growth in Europe's regions? Papers Reg. Sci. 2016. [CrossRef]

57. Charron, N. Explaining the allocation of regional Structural Funds: The conditional effect of governance and self-rule. Eur. Union Politics 2016, 17, 1-22. [CrossRef]

58. Ministero dello Sviluppo Economico. Quadro Strategico Nazionale per la Politicaregionale di Sviluppo 2007-2013; Dipartimento per le Politiche di Sviluppo e Coesione: Rome, Italy, 2007.

59. European Union. La Politica di Coesione 2007-2013, Osservazioni e Testiufficiali, Commissioneeuropea, Direzione Generale Della Politica Regionale; European Union: Brussels, Belgium, 2007.

60. Maroto, A.; Gallego, J.; Rubalcaba, L. Publicly funded R \& D for public sector performance and efficiency: Evidence from Europe. R D Manag. 2016, 46, 564-578.

61. Kaufmann, D.; Kraay, A.; Mastruzzi, M. The Worldwide Governance Indicators: Methodology and Analytical Issues. Hague J. Rule Law 2011, 3, 220-246. [CrossRef]

62. Charron, N.; Dijkstra, L.; Lapuente, V. Mapping Quality of Government in the European Union: A Study of National and Sub-National Variation; QoG Working Paper; European Union: Brussels, Belgium, 2010.

63. Charron, N.; Lapuente, V.; Dijkstra, L. Regional Governance Matters: A study on Regional Variation in Quality of Government within the European Union Member States. Reg. Stud. 2012, 48, 68-90. [CrossRef]

64. Mila, T.; McGuire, T.J. The contribution of publicly provided inputs to states' economies. Reg. Sci. Urban Econ. 1992, 22, 229-241. [CrossRef]

65. Tomljanovich, M. The Role of State Fiscal Policy in State Economic Growth. Contemp. Econ. Policy 2004, 22, 318-330. [CrossRef]

66. Dye, T.; Feiock, R.C. State income tax adoption and economic growth. Soc. Sci. Q. 1995, 76, 648-654.

67. Bleaney, M.; Gemmell, N.; Kneller, R. Testing the endogenous growth model: Public expenditure, taxation, and growth over the long run. Can. J. Econ. 2001, 34, 36-57. [CrossRef]

68. Daniele, V.; Malanima, P. Il prodotto delle regioni e il divario Nord-Sud in Italia (1861-2004). Riv. Politica Econ. 2007, 97, 267-316.

69. Asatryan, Z.; Heinemann, F.; Pitlik, H. Reforming the Public Administration: The Role of Crisis and the Power of Bureaucracy. 2016. Available online: http:/ / dx.doi.org/10.1016/j.ejpoleco.2016.08.004 (accessed on 5 August 2017).

2017 by the authors. Licensee MDPI, Basel, Switzerland. This article is an open access article distributed under the terms and conditions of the Creative Commons Attribution (CC BY) license (http://creativecommons.org/licenses/by/4.0/). 